(iv) A nearly homogeneous treatment can be inferred from the slightness of the positive correlation between breaks within cells.

(v) In certain other species of plants, namely, Rhoo discolor, Muscari plumosus and Scilla sibirica, which have visible heterochromatin, maleic hydrazide has failed to break the chromosomes.

Maleic hydrazide differs from other chromosomebreaking agents in not providing a sticky chromosome surface.

Indeed, whereas other agents have shown some similarity in effect with $\mathrm{X}$-rays ${ }^{8}$, here for the first time we have a sharp contrast. $X$-rays break the euchromatin only ${ }^{\theta}$ maleic hydrazide breaks the heterochromatin only. The new agent may even be a means, therefore, of defining specific kinds of gene in the heterochromatin.

Since nearly all chromosome-breaking agents have so far proved to be cancer-producing as well, we must hope that the agricultural use of this new agent will not be encouraged before suitable tests are made. C. D. Darimgton JOHN MCLEISH

John Innes Horticultural Institution,

Bayfordbury, Hertford, Herts. Dec. 19.

'Wittwer, S. H., and Sharma, R. C., Science, 112, 598 (1949). ${ }^{2}$ (Currier, H. P., and Crafts, A. S., Science, 111, 152 (1950). ${ }^{3}$ White, D. G., Discovery, 11, 379 (1950).

4 Naylor, A. W., and Davis, E. A., Bot. Gaz., 112, 112 (1950).

${ }^{5}$ La Cour, L. F., Heredity, 5, 37 (1951).

6 Ford, C. E., Proc. 8th Int. Gen. Congr. (Stockholm), p. 570 (1949). 'Loveless, A., and Revell, S., Nature, 164, 938 (1949).

- Darlington, C. D., and Koller, P. C., Heredity, 1, 185 (1947).

- Darlington, C. D., and La Cour, L. F., J. Genet., 46, 180 (1945).

\section{Crystalline Structure of the Cuticular Sheath of Wool Fibres}

IN a recent communication in Nature ${ }^{1}$, Alexander and Earland have described experiments in which wool keratin has been rendered soluble in dilute ammonia by pretreatment with peracetic acid. In these experiments they obtained an insoluble sheathlike residue, presumably the remains of the cuticle, amounting to some 10 per cent of the original fibre weight, and found, in collaboration with Happey ${ }^{2}$, that this material gave a $\beta$-type $X$-ray photograph.

Since Alexander, Earland and Happey attach considerable importance to this result, believing that it implies the existence of a $\beta$-crystalline component in the cuticle of untreated fibres, and that this plays an important part in determining the technological behaviour of wool fibres, we have considered it worth while to examine the residues obtained by treating Lincoln wool fibres in 3 per cent peracetic acid and then in $0.1 N$ or I $N$ ammonia. In none of our experiments, which covered a wide range of times of treatment in the acid and alkali, were we successful in obtaining a residue showing an $\mathrm{X}$-ray photograph of the $\beta$-type ; in our more mildly treated preparations we obtained an $\alpha$-photograph, and in the rest one which could not be described as either $\alpha$ or $\beta$, showing only the diffuse halos with spacings about $10 \mathrm{~A}$. and 4-5 A. which are commonly apparent in the photographs of poorly crystalline proteins in general.

Electron microscope photographs of the residues showed that there usually remained, besides the sheath-like structure described by Alexander and
Earland, some other fibrous material. We have examined (by courtesy of Dr. Olofsson, of the Swedish Institute for Textile Research) electron micrographs of material supplied by Alexander, and these showed a similar heterogeneity. In our preparations, therefore, and probably also in those of Alexander and Earland, the insoluble residue contained some corticle material.

We should like to suggest, therefore, that the $\beta$-photograph obtained by Happey does not necessarily prove the existence of crystalline $\beta$-keratin in the untreated fibre, and that the $\beta$-form may have been produced during their experiment from originally $\alpha$-type keratin. That this may easily happen is shown by some of our experiments, in which residues dried at $40^{\circ} \mathrm{C}$. undoubtedly contained protein of the $\beta$-type, although the same material dried at $20^{\circ} \mathrm{C}$. gave the ordinary $\propto$ X-ray photograph.

\section{N. Peacock \\ J. SIKORSKI \\ H. J. Woods}

Textile Physies Laboratory,

Department of Textile Industries, University of Leeds.

Dec. 21.

${ }^{1}$ Alexander and Earland, Nature, 166, 396 (1950). [See also Mariner, Nature, 167, 231 (1951).]

Happey, Nature, 166, 397 (1950).

\section{Enzymatic Synthesis of Deoxypentose Phosphate}

LITTLE is known about the pathway of biological synthesis of deoxypentose. As a component of deoxypentose nucleic acid, the synthesis of this sugar must play an important part in the metabolism of cell nuclei.

It has been possible to demonstrate one pathway of enzymic synthesis of deoxypentose from triosephosphate and acetaldehyde. Extracts of $E$. coli, C. diphtherice and St. fecalis prepared by sonic disintegration of the bacterial cells or by grinding with alumina are capable of catalysing the reversible reaction :

Glyceraldehyde phosphate + acetaldehyde $\rightleftharpoons$ deoxypentose phosphate.

The heat-labile enzyme which catalyses this aldol condensation has been purified about eight-fold from extracts of $E$. coli.

As shown in the accompanying table, the formation of deoxypentose, measured by the diphenylamine colour reaction, is dependent on the addition of aldolase, hexose diphosphate (used as source of triose phosphate) and of acetaldehyde. A dichromatic

\begin{tabular}{|l|c|c|}
\hline & \multicolumn{2}{|c|}{$\begin{array}{c}\text { Deoxypentose phosphate } \\
\mu \text { gm./mgm. protein } \\
\text { Crude extract } \\
\text { Purifled enzyme }\end{array}$} \\
\hline Complete system* & 70 & 580 \\
Aldolase omitted & 45 & 70 \\
Acetaldehyde omitted diphos- & 0 & 0 \\
Aldolase and hexose dipho \\
phate omitted \\
$\begin{array}{c}\text { Complete system deproteinized } \\
\text { at zero time }\end{array}$ & 3 & 0 \\
\hline
\end{tabular}

* The complete system contains $0.02 M$ of fructose diphosphate $0.02 M$ acetaldehyde, $0.05 M$ potassium phosphate buffer $p \mathrm{H} \quad 7 \cdot 4$ $200 \mu \mathrm{gm}$. of crystalline aldolase from rabbit muscle and about $1-4 \mathrm{mgm}$. of protein of the enzyme preparation in a final volume of $1 \mathrm{ml}$. After $30 \mathrm{~min}$. incubation at $37^{\circ}$, the mixtures were deproteinized with an equal volume of 5 per cent trichloracetic acid, and deoxypentose was determined on an appropriate sample by the diphenylamine colour reaction. 